\title{
RISK FACTORS OF TYPE 2 DIABETES MELLITUS IN YOGYAKARTA
}

\author{
Sesrima Yenti, Nur Alvira Pasca Wati, Ayu Fitriani \\ Respati University, Yogyakarta
}

\begin{abstract}
Background: Diabetes Mellitus (DM) is a non infectious disease with an increasing trend in Indonesia. This study aimed to investigate the risk factors of Type 2 Diabetes Mellitus in Yogyakarta.

Subjects and Method: This was a case control study conducted in Yogyakarta. A sample of 80 study subjects consisting of 40 patients with DM and 40 without DM were selected for this study. The dependent variable was DM status. The independent variables were age, sex, and family history. Data were collected by questionnaire and analyzed by multiple logistic regression.

Results: Age $\geq 40$ years old $(\mathrm{OR}=31.22 ; \mathrm{p}=0.032)$, female $(\mathrm{OR}=7.32 ; \mathrm{p}=$ $0.055)$, and family history $(\mathrm{OR}=13.6 ; \mathrm{p}=0.054)$ were associated with an increased risk of type 2 Diabetes Mellitus.

Conclusion: Age $\geq 40$ years old, female, and family history are risk factors of type 2 Diabetes Mellitus.
\end{abstract}

Keywords: Type 2 Diabetes Mellitus, age, sex, family history

Correspondence: Nur Alvira Pasca Wati. Respati University, Yogyakarta. Email: irha011185@yahoo.com. Mobile:+628176616928. 